\title{
Library Overhead Allowances under Government Research Agreements
}

\begin{abstract}
With the issuance of the March 1965 revision of U.S. Bureau of the Budget Circular A-21, there are significant improvements in the reimbursement method for indirect library costs under Government research agreements. Major changes are outlined. The necessary supporting analysis of library costs is discussed, and there is reference to a recent study of costs at Stanford University.
\end{abstract}

$\mathrm{U}$ NIVERSITIES WITH United States government research grants and contracts have new reason to study the full costs of their libraries. This interest results from the government's method of calculating reimbursable indirect or overhead costs. Indirect costs include those for library service, and the library component can be a very large sum.

The government's method of calculating the library part of overhead costs was subjected to wide criticism when the War Department "Blue Book" was issued in 1947. It was not improved in the superseding Circular No. A-21 issued by the Bureau of the Budget in 1958 and revised in 1961. The result was the series of cost studies prepared by librarians and the meetings of librarians and financial officers held in 1960, as reported by R. H. Logsdon. ${ }^{1}$

The recommendations of these individuals, followed by the continuous efforts of the various university financial officers, have now resulted in a substantial and gratifying revision of Circular

\footnotetext{
${ }^{1}$ Richard H. Logsdon, "Indirect Costs of Library Services Under U.S. Research Agreements," $C R L$, XXIII (January 1962), 24-27.
}

$\mathrm{Mr}$. Weber is Associate Director of $\mathrm{Li}$ braries, Stanford University.
A-21 under date of March 3, 1965. It is there noted that the revised "Principles for Determining Costs . . . will be applied at the earliest practicable date."

The revised circular is significant with regard to library costs in two main areas. One of these is the treatment of expenditures for book materials. In the 1961 document, books were allowed a "use allowance" which "shall not exceed eight cents per volume per year." Where library statistics for volumes in the collection are universally subject to question, this basis for assigning costs certainly rested on quicksand. As of 1965 these book expenditures are included as annual operating expenses. All current expenditures for book materials will now be included, although credit must be given for fine income for lost or damaged books, and the cost of books purchased for office collections or other collections not part of the formally organized library may be excluded.

The other significant change is in the implied acceptance of the fact that library expenses are much heavier for graduate programs than for the undergraduate. Thus in 1961 the library personnel expenses and other expenses except those for book materials were to be 
allocated "on the basis of population including students and other users." It continued that "where appropriate, consideration may be given to weighting segments of the population figures as necessary to produce equitable results." This put the burden of proof on the university, and government auditors gave way very little in permitting weighting. The 1965 revision still bases distribution on population. However it goes on to indicate greater acceptance of weighting by explaining that the distribution may be "on a selective basis" made "through use of reasonable methods which give adequate recognition to the utilization of the library attributable to faculty, research personnel, students and others. The method used will be based on data developed periodically on the respective institution's experience for representative periods."

These changes constitute a notable step forward for universities having government research agreements where these principles are applied and where the resulting allocation of costs are substantially reimbursed.

The document prompts universities to undertake studies to determine the extent to which books are acquired for undergraduate students, together with the associated costs of cataloging, preserving, and storing such acquisitions. With these costs excluded, the remaining costs in support of research would be allocated among graduate students, faculty, and other users on population or other equitable basis.

The proper distribution of library costs is complicated by several factors. One is the special effort required to obtain all full library costs, including personnel benefits and plant operation and maintenance for all library units. Another aspect is the judgment required of whether a particular book was selected for its support of the undergraduate curriculum or of research programs. This same judgment is necessary of all serial titles. Then there is the need to have a sample breakdown of circulation by type of user for each library service unit, a sample that is statistically valid for the relevant twelve months. Many lesser problems could be added. Yet, although there are bound to be some gray areas, a cost study will be considered reasonable and useful if sound analytical methods are utilized and reasonable allocations are made using current data collected in an unbiased manner.

That these complicating factors can be overcome is demonstrated by the detailed cost analysis made during 1961-62 of the Purdue University libraries by Gerald L. Quatman ${ }^{2}$ and during 1964 of the Stanford University library system by Glen Densmore and Charles Bourne. ${ }^{3}$

The various steps taken in the Stanford study are too detailed for a brief report; however, the variety of approach may be suggested by mention of the choice of particular methods by which costs were allocated to user groups. For example, book costs and periodical costs were separately allocated by population after identification and removal of the undergraduate portion. Public service staff salaries were allocated by recorded circulation after subtracting time spent on book selection and technical processing. Technical processing salaries were allocated on the basis of a combined book and periodical division after being modified to include gift and exchange material. Other means of allocation had to be used for operation and maintenance costs and for building, furniture, and equipment depreciation.

In addition, the study included five special surveys to aid in the allocation of cost elements to each of the user groups. These studies covered a circulation analysis and physical census and

\footnotetext{
2The Cost of Providing Library Services to Groups in the Purdue University Community-1961. (Lafayette, Ind.: Purdue University Libraries, 1962.)

${ }^{3} A$ Cost Analysis and Utilization Study of the Stanford University Library System. (Menlo Park, Calif.: Stanford Research Institute, 1965. Available from Stanford University Libraries.)
} 
TABLE 1

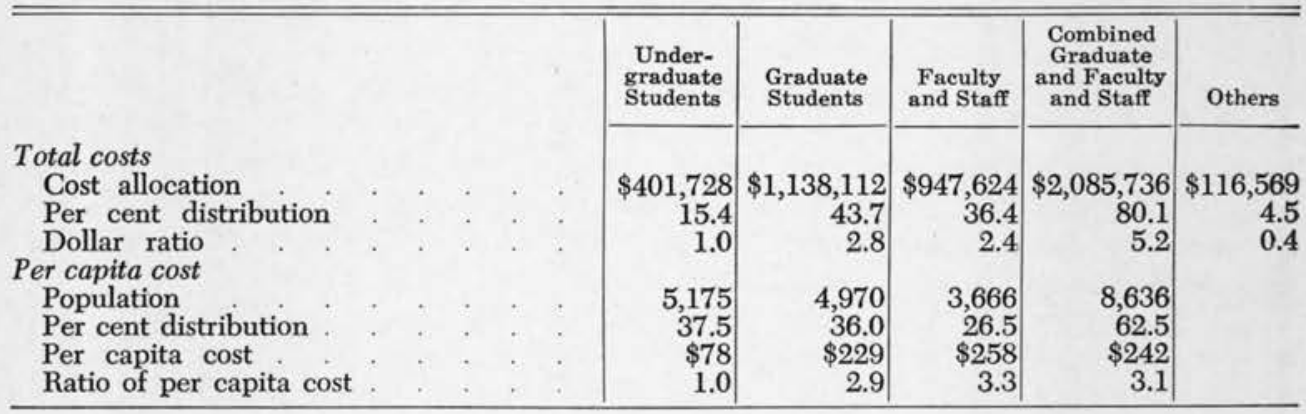

interviewing of persons using the facilities, an analysis of students and academic and nonacademic staff on a twelve month equivalent, a major sample of acquisition and cataloging staff time spent on undergraduate and research books, the subtraction of technical processing time from public service staff time, and the division of all library buildings into public, technical processing, and book storage space.

From this type of study, a simple table results which can then be applied in weighting users under government cost determination. In Stanford's case, the results were:

This supports the premise that the costs of library service to graduate instruction and research are substantially higher than those for undergraduate instruction. In Stanford's case the population weighting should be 3.1 to 1 . In 1960 the California Institute of Technology found that the research component should be weighted 3 to 1 . Harvard's figure was 3.3 to 1 . Cornell's and Purdue's figures were somewhat below this level while Michigan's was above.

Such studies provide the quantitative base for pursuing negotiation with the government on the library costs properly allocable to research agreements. The legitimate result can be a very substantial increase in the recovery of indirect costs by the university.

\section{Eastern College Librarians}

THE FIFTY-FIRST Conference of Eastern College Librarians at Harkness theater in Butler library, Columbia University, New York, will deal with Current Statewide Library Developments, in the morning session on Nov. 27; the afternoon session will be devoted to discussions on Books and Publishing. Beginning at 10 a.m., James Skipper, executive secretary of the Association of Research Libraries, will discuss the National Scene; Walter Brahm, director of the Connecticut state library, will view the topic as concerned with Connecticut; Morris Gelfand, librarian of Queens College, will provide information about New York State; and Norman Stevens, associate librarian, Rutgers University, will report on New Jersey. At 1:30 p.m., J. Donald Adams, former editor, New York Times Book Review, will survey the Contemporary Literary Scene; Peter Jennison, executive director of the National Book Committee, will tell his listeners What's Wrong with Book Publishing Today; and Trends in Soviet Scientific Publishing will be discussed by M. M. Oberlander, president of Faraday Press. S. Gilbert Prentiss, director of the New York state library, will preside during the morning, and Richard Logsdon, director of libraries, Columbia University, will preside during the afternoon session. 